\title{
Indonesian traditional dance: ethnomathematics on culture as a basis of learning mathematics in elementary schools
}

\author{
Rachmaniah Mirza Hariastuti, Universitas Negeri Surabaya/Universitas PGRI Banyuwangi, Indonesia, \\ rachmaniah.18004@mhs.unesa.ac.id ORCID :0000-0002-7944-8443 \\ Mega Teguh Budiarto, Universitas Negeri Surabaya, Indonesia, megatbudiarto@unesa.ac.id ORCID \\ 0000-0002-9052-3141
}

Manuharawati, Universitas Negeri Surabaya, Indonesia, manuharawati@unesa.ac.id ORCID : 0000-00031030-7295

\begin{abstract}
Traditional dance is part of a culture that has a deep philosophy and contains various knowledge. Gandrung Jejer Jaran Dawuk (GJJD) dance is a traditional dance from Banyuwangi-Indonesia which is still taught to students in elementary and secondary schools. This study aims to explore the GJJD dance motions carried out singly, identify ethnomathematics in the GJJD dance motions, and determine whether the identified ethnomathematics can be applied to mathematics learning in elementary schools. The method used is a qualitative with ethnographic approach. Research informants are GJJD creators, dance trainers, and the dancers from Banyuwangi who are still actively doing GJJD dance. GJJD dance contains variations of motion that can be classified into : footwork, body, head, and hand motions. The identification of the motion variations obtained shows that there are mathematical concepts, namely : counting numbers in all motions, number pattern in footwork, angle in all motions, and the position of the object based on the compass point in footwork and body motions. The concepts identified are found in mathematics learning in elementary schools. Ethnomathematics of GJJD dance motion can be used as a basis for learning mathematics in elementary schools in the form of thematic learning.
\end{abstract}

Keywords: Gandrung Jejer Jaran Dawuk dance, Dance motions, Ethnomathematics, Mathematical concepts, Elementary schools.

Received: 21.11.2020 Accepted: 10.12.2020 $\quad$ Published: 09.01.2021

\section{INTRODUCTION}

Thematic learning is a form of learning that integrates several subjects in one theme with the aim of providing meaningful learning experiences for students (Varun A, 2014; Ain, 2017; Chumdari, Anitah, Budiyono, \& Suryani, 2018). Varun, mentioned thematic learning as a learning approach which involves many curriculum areas connected and integrated in a theme. Ain defines thematic learning as learning model that integrates multiple subjects that is bound by the theme. While Chumdari et al. states that thematic learning model is a learning model designed based on a spesific theme with the aim of providing meaningful learning experiences for students.

Thematic learning can be applied using cultural themes that are close to students' daily lives. Thematic models in cultural contexts are needed in learning at the elementary level, one of which is in understanding basic mathematical concepts. This is in accordance with the existence of mathematics which is "comprised of a diversity of practices that make it as historically, culturally, socially, and politically situated as any other human activity" (Greer, Mukhopadhyay, Nelson-Barber, \& Powell, 2009). This shows that many mathematical concepts can be identified in cultural activities. For this reason it is necessary to explore mathematical concepts in culture before they are used as thematic learning material.

Mathematical concepts that can be identified in the culture of society are known as ethnomathematics. D'Ambrosio (2001) mentioned that "ethnomathematics is the mathematics practiced by cultural groups, such as urban and rural communities, groups of workers, professional classes, children in a given age group, indigeneous societies, and so many other groups that are identified by the objectives and traditions common to these groups". To find out the ethnomathematics of a culture, it is necessary to explore the culture, then identify the mathematical concepts contained in that culture.

Ethnomathematics that have been identified from a society's culture can be used as a basis for learning, one of which is elementary education. Owens, Edmonds-Wathen, \& Bino (2015) stated that there was a need (especially at the elementary level) to understand mathematics in culture and its relationship with mathematics in schools. Spradley (1979) explained that "culture refers to the acquired knowledge that people use to interpret experience and generate social behavior". D'Ambrosio (2001b) 
said that culture is parts of a nation, community, or group that share knowledge, such as language, life systems, spiritual and customary activities, culinary habits, and behavior, in accordance with the agreed value system in the community. All of these opinions indicate that various things around humans that become habits in certain groups and are taught from one generation to the next is a culture.

Ethnomathematics research in Indonesia shows the cultural diversity that is owned by the people in Indonesia. The exploration of ethnomathematics in the traditional house Using Banyuwangi by Hariastuti, Budiarto, \& Manuharawati (2019) shows that Using house construction contains mathematical concepts such as two-dimensional geometry, pythagoras, and similarity. Utami, Sayuti, \& Jailani (2020)'s research results show that there is ethnomathematics on the Javanese Calender in form the reminder and arithmetic modulo to determine of days on weekly cycles and pasaran. While exploration that has been done by Fendrik, Marsigit, \& Wangid (2020) on Pacu Jalur game (Riau traditional game) shows the concept of tubes in geometry that can be used in mathematics learning to develop mathematical connection abilities of elementary school students.

Ethnomathematical exploration research on culture was also carried out on traditional dances in Indonesia. Research conducted by Ma'Rifah, Widada, Aida, Yulfitri, \& Effendi (2018) shows that there is a geometry concept in the form of a kite in Kejei dance from Rejang Lebong District. Exploration of Saman dance (the traditional dance from Aceh) shows that the composition of dancers in the opening of the 2018 Asian Games includes mathematical concepts, such as 2-dimentional objects and sets (Maryati \& Pratiwi, 2019). On the Caci dance (the traditional dance from Manggarai, Nusa Tenggara Timur) shows the concepts of geometry, sets, relations, and functions as well as measuring and quantifying activities in the attributes used and dance rules (Maure \& Ningsi, 2018). The results of these studies indicate that ethnomathematical exploration has been carried out in various Indonesian traditional dances, but has not been specifically carried out on the GJDD dance from Banyuwangi.

"Dance is considered to be patterned and rhythmic bodily movements, usually performed to music, that serve as a form of communication or expression" (Charles \& Justin, 2014). Georgios (2018) states that "the traditional bears elements of our cultural tradition and heritage and passes them down from generation to generation". Saputra, Supriyadi, \& Demartoto (2019) explained that "traditional dance implies a message from the community in the form of knowledge, ideas, beliefs, values, and norms". These opinions shows that traditional dance is a part of culture in which there is knowledge and traditional values handed down from one generation to the next. So that learning with the theme of traditional dance can contribute to cultural preservation as well as understanding concepts.

Banyuwangi is one of the city in Indonesia which has a variety of traditional dances, one of which is Gandrung Jejer Jaran Dawuk (GJJD) dance. GJJD is one of the creations of Gandrung dance from Banyuwangi which is still taught to students in elementary and secondary schools. Hadi (1980) mention that Jejer Jaran Dawuk can be interpreted as a dance that describes the motion of a dawuk horse with active character. This meaning appears the agility of dance motions performed by dancers.
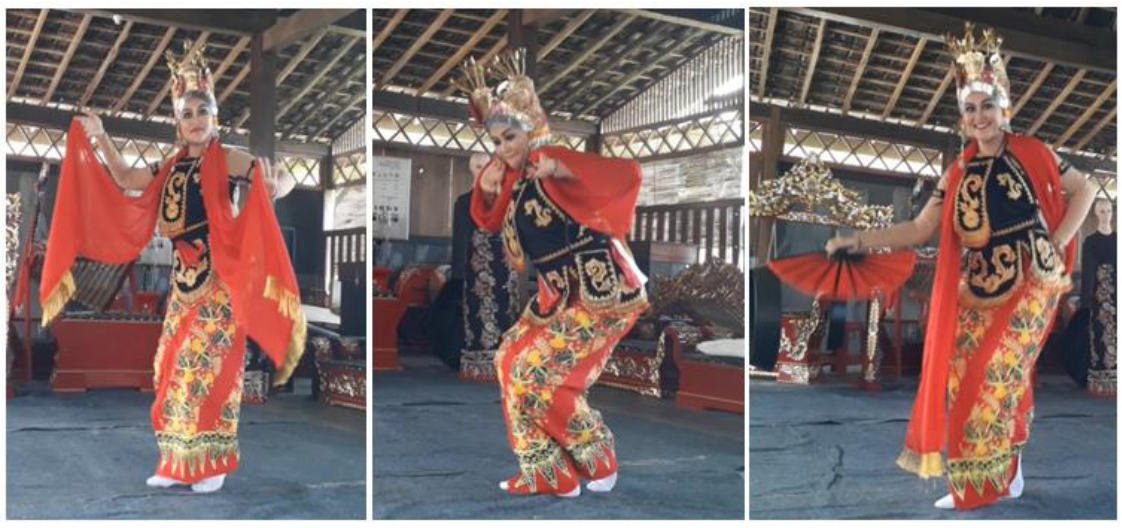

Figure 1. Some motions on GJJD dance (researcher documentation)

Hadi (1980), who is the creator of GJJD dance, divide the sequence of motions GJJD dance into three parts, as follows : part 1 (contains the dancer's motions entering the stage and the first part's combining the motions of the legs, arms, body, and head, which uses a shawl); part 2 (the second part's contains a combination of motion between the legs, arms, body, and head, which uses a shawl and hand fan); and part 3 (the third part's contains a combination of motion between the legs, arms, body, and head, still uses a shawl and hand fan, and ending with a move out of the stage). Each of these motions has special characteristics, must be done in sequence, and has a certain rhythm (motion count). 
Specifically, ethnomathematics research on single GJJD dance motion has never been done. Previous studies have focused more on dance patterns conducted in groups. The results of this study indicate the existence of measuring activities on determining the distance between dancers by using nonstandard measures; counting activity on determining the start time of the dance and motion changes; and motion design activities (in the form of designing lines, angels, and 2-dimentional objects) on the dance floor pattern (Sandhi et al., 2018).

The focus of this research is to identify the corresponding ethnomathematics froms the GJDD dance which will then be used as the basis for thematic learning in elementary schools.

\section{METHODS}

This research was conducted qualitatively with an ethnographic approach from February to May 2020. Research has been carried out to explore GJJD's single dance motions and mathematical concepts that can be identified in each of these dance motions. The ethnographic approach is used to identify mathematical concepts in the GJJD dance motions that will be used in thematics learning in elementary schools.

\section{Research Informant}

This research produces data in the form of descriptions and documentation of GJJD dance motions. Data sources are informants involved in dance activities in Banyuwangi and are determined purposively. There were five informants in this study who were selected according to the intended cultural conditions and were communicative, that is : one creator of GJJD dance and dance trainer, two dance trainers who have trained for at least 10 years, and two dancers who have practiced and danced at the "Gandrung Sewu" festival. The informants were selected because they were people who had at least 5 years of experience in their fields.

\section{Data Collection Methods}

Data collection in this research was carried out using participatory observation, in-depth interviews, and cultural documentation (Spradley, 1979). Research was conducted based on following flow.

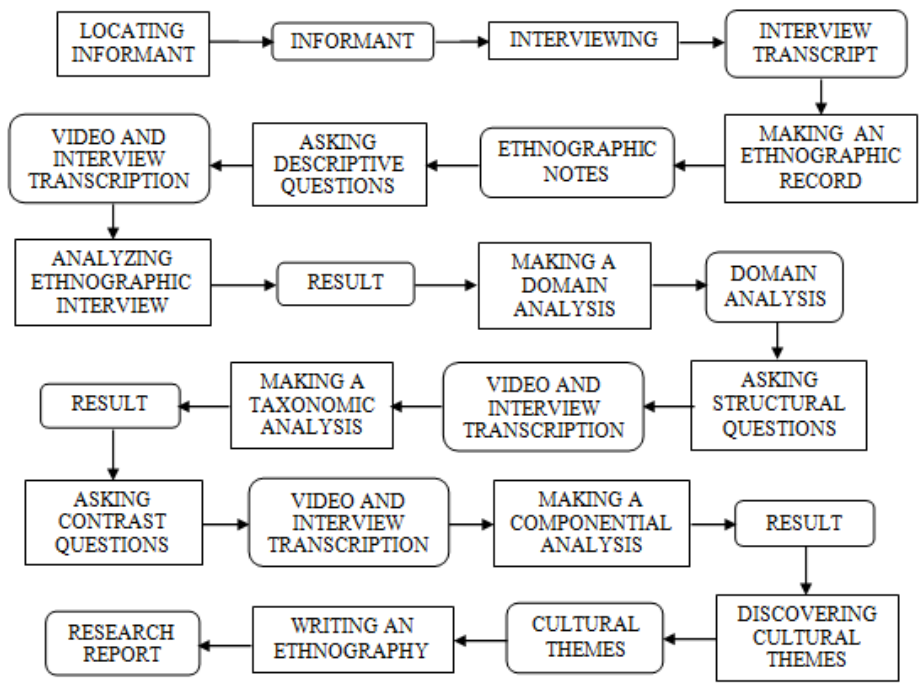

Figure 2. Research Flow

Observation and interviews were conducted to explore every motion in GJJD dance. Documents collected in the form of videos, picture, and literature related to the GJJD dance motion are used as a supplement to the description obtained from observation notes and interview. The guide is used to direct the process of observation and interviews to focus on the GJJD dance motions. So that the observation guide contains indicators in the form of GJJD dance motions according to Hadi (1980). While the interview guide contains indicators in the form of dance sequences, confirmation of motion names, and how the motions should be performed.

\section{Data Analysis}

Qualitative research with an ethnographic approach (Spradley, 1979) is carried out in the form of exploration according to the natural conditions of the research object. The data obtained were analyzed 
throughout the research process together with the data collection and writing of findings (Creswell, 2013). Data analysis was carried out flexibly but deeply based on indicators of mathematical concepts that can be found in the GJJD dance motions. As stated by Boellstorff, Nardi, Pearce, \& Taylor (2012) that "an ethnographic methodology extends this kind of flexible approach into the data analysis phase, and the most fundamental approach to data analysis is to engage in rigorous intellectual process of working deeply and intimately with ideas". Data validity and reliability were tested according to the steps of the ethnographic approach.

\section{RESULTS}

\section{Gandrung Jejer Jaran Dawuk Dance Motions}

Generally Gandrung Jejer Jaran Dawuk (GJJD) dance describe the behaviour of the "dawuk" horse which is very active and agile. Informants in this study are : (1) Sumitro Hadi (GJDD dance creator), (2) Samsul (dance teacher at SMK Negeri Banyuwangi), (3) Supinah (Gandrung dancer, Gandrung trainer, and the owner of dance studio "Sayu Sarinah" Olehsari Banyuwangi), (4) Rima (Gandrung dancer), and (5) Tirta (Gandrung dancer). The results of interviews with informants (2), (3), (4), and (5) show that they understands the GJJD dance sequence and can do it well, but they does not understand the terms of each motions. So that the main informant who can explain the terms of the motion is Sumitro Hadi. Exploration results show that the GJJD dance contains three parts in accordance with what Hadi (1980) said.

\section{Table 1. Gerak Tari Gandrung Jejer Jaran Dawuk}

\begin{tabular}{|c|c|}
\hline PART & MOTION AND DESCRIPTION \\
\hline \multirow[t]{12}{*}{1} & $\begin{array}{l}\text { Dancers enter the stage; fast footwork (is called langkah nyiji kerep); upper head motion } \\
\text { shaking to the right and left around } 30^{\circ} \text { (is called deleg duwur); hands pinning the shawl } \\
\text { (is called jejeb) and swings up and down (is called ngiwir sampur) }\end{array}$ \\
\hline & $\begin{array}{l}\text { The kendang is played, the dancer performs : rotating body motions with straight hand } \\
\text { forming an angle of } 180^{\circ} \text { (is called glebegan left-right); palms rotated with a fulcrum on } \\
\text { the wrist (is called ukel); walking steps (is called langkah nyiji) with a slight heel lift (is } \\
\text { called jinjit); the hands and arms are straight with the palms and fingers vibrated (is called } \\
\text { ngeber); posture of respect (left foot in front of the right foot, body bent, right hand in } \\
\text { front of the body with respect, left hand straight back) }\end{array}$ \\
\hline & $\begin{array}{l}\text { Kudangan kluncing, i.e : the sentences spoken by the player of the kluncing/musical } \\
\text { instrument in the form of a triangle, to guide the next dancer's motions. }\end{array}$ \\
\hline & $\begin{array}{l}\text { Circular body motions left then right; langkah nyiji kerep; two footwork (double step); the } \\
\text { right hand is held up at the level of the ear and the thumb forming an angle of } 90^{\circ} \text { with the } \\
\text { other four fingers pressed together (ia called cangkah) and left hand cangkah goes down } \\
\text { to the waist, vice versa (the chain of motion is called ngayun); ngayun with fingers } \\
\text { pinching and swinging shawls (is called ngiwir sampur). }\end{array}$ \\
\hline & $\begin{array}{l}4 \text { times langkah nyiji ; body leaning to the right; the right hand cangkah upward to the } \\
\text { extent of the ear and the left hand cangkah downward to the waist; finger pinch the shawl. } \\
\text { This motion is carried out alternately to the right and left } 2 \text { times each. }\end{array}$ \\
\hline & $\begin{array}{l}\text { Songkloh left-right, that is : ndelengkeng (chest pulled forward, buttocks pulled back); } \\
\text { hand motion leaning back slightly around } 45^{\circ} \text {; shoulders raised alternately left and right } \\
\text { and together. This motion is done with the body facing right and left alternately. }\end{array}$ \\
\hline & $\begin{array}{l}\text { Move the right shawl to the left arm; footwork goes ti the left side with the right foot in } \\
\text { front of the left foot and vice versa (is called sirig left-right) with hips to the left and right } \\
\text { (is called egol) }\end{array}$ \\
\hline & Double step; circle left and right; ngayun; ngiwir sampur \\
\hline & $\begin{array}{l}4 \text { times langkah nyiji; } 4 \text { times langkah nyiji kerep; shoulders tiptoe to the left and right and } \\
\text { the shawl is carried over the shoulder (is called mikul sampur); deleg duwur; leaning } \\
\text { forward. This motion is carried out in } 4 \text { directions (front, left, back, right) }\end{array}$ \\
\hline & $\begin{array}{l}\text { Both hands shake the shawl in the front with teh body position slanted dengan posisi } \\
\text { badan serong and walking foot steps (is called gebyar sampur) } 4 \text { times alternately } \\
\text { dragging left and right }\end{array}$ \\
\hline & $\begin{array}{l}\text { Footwork walking backwards (is called langkah nyiji); the shawl is carried over the } \\
\text { shoulder (is called mikul sampur); neck and chin motions to the left and right (is called } \\
\text { deleg gulu). Motion carried out as much as } 3 \times\end{array}$ \\
\hline & Tinjakan right-left-right, i.e : the motion of the hand raising the shawl; both hands \\
\hline
\end{tabular}




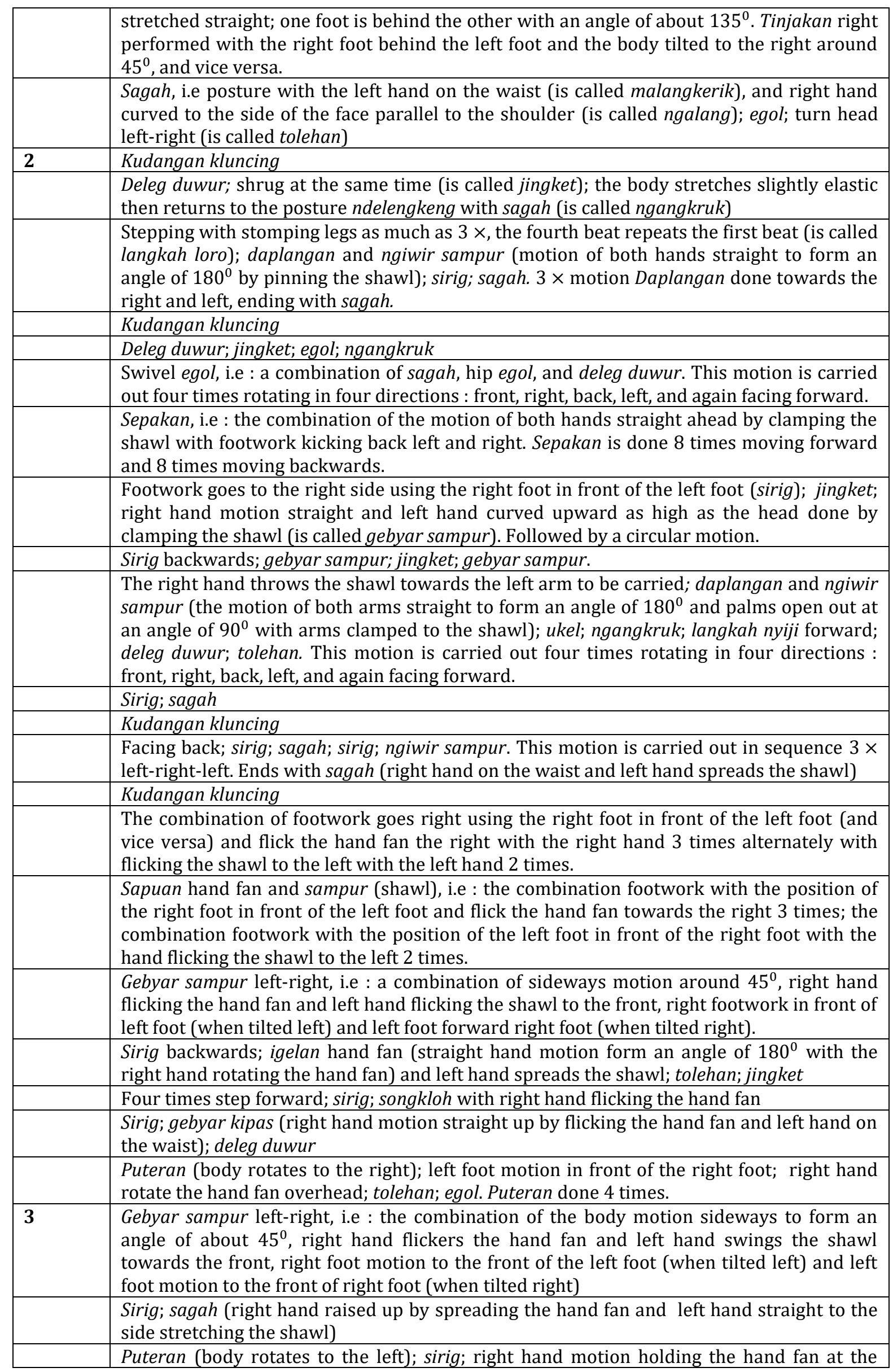




\begin{tabular}{|l|l|}
\hline & waist and left hand cangkah above the head; deleg duwur; egol. Puteran done once. \\
\hline $\begin{array}{l}\text { Ngembat, i.e : a combination of footwork stepping with stomping feet similar to langkah } \\
\text { loro but at the 2, 3, 4 beat followed by body elasctic motion like a spring (is called embat); } \\
\text { egol; deleg; and jingket. Ngembat done with the left hand mikul sampur and right hand } \\
\text { holding the hand fan on the waist. }\end{array}$ \\
\hline $\begin{array}{l}\text { Langkah nyiji kerep; daplangan; right hand flickers the hand fan and left hand spreads the } \\
\text { shawl, the dancer walks out of the stage }\end{array}$ \\
\hline
\end{tabular}

\section{Domain Analysis and Taxonomic Analysis}

GJJD dance contains four main motions, namely the motions of the feet, body, head and hands that move together. Sumitro Hadi stated that the feet provide the support of body movement, and balanced body motion can be done if the position of both feet forms an angle of about $90^{\circ}$, knees form an angle of about $135^{\circ}$, and the soles of the feet can move elasticly with a slight tiptoe (is called jinjit) so that the steps of the dancer look swinging. As conveyed by Hadi (1975), that there are three rules of footwork in the Banyuwangi dance which are the basis for performing dance motions. The footwork is shown in Figure 3.

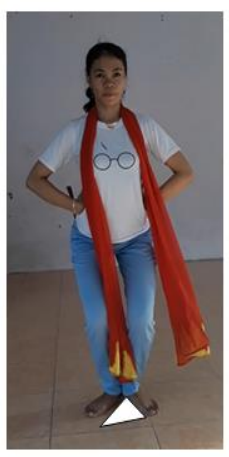

ANGLE $90^{\circ}$

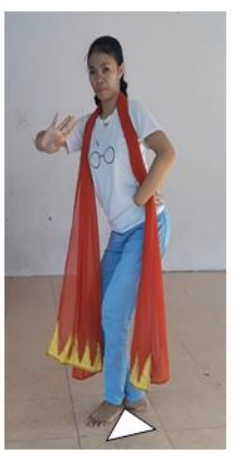

ANGLE $90^{\circ}$

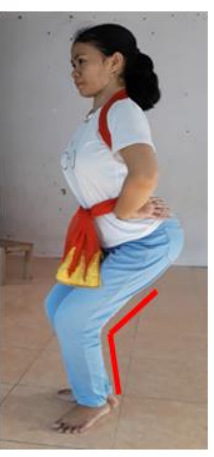

ANGLE $135^{\circ}$

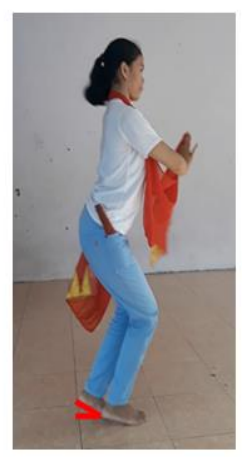

IINIIT

Figure 3. Describes the rules of footwork in the GJJD dance (researcher documentation)

The footwork in the GJJD dance can be done with langkah nyiji, langkah loro, langkah double step, and sirig. These steps cannot be shown in the form of images, but can be described as in table 1 . In addition there is the development of footwork, namely ngembat and sepakan, as showed in Figure 4.

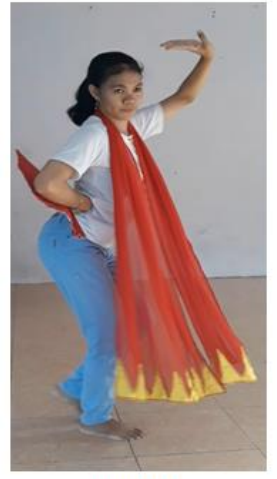

NGEMBAT

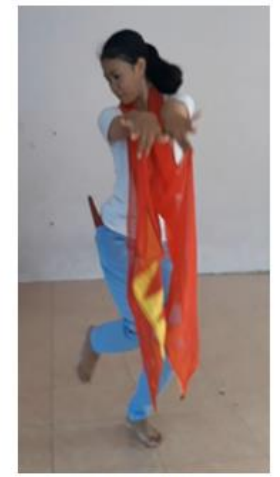

RIGHT SEPAKAN

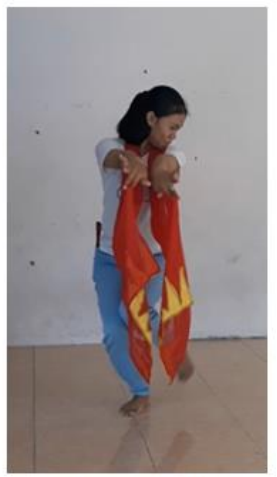

LEFT SEPAKAN

Figure 4. Describes the motion ngembat and sepakan (researcher documentation)

The body motion used in the GJJD dance are ndelengkeng and ngangkruk. Body motions also contain hip and shoulder motions. Hip motion used is egol, while shoulder motion is called jingket. The body motions is shown in Figure 5. 


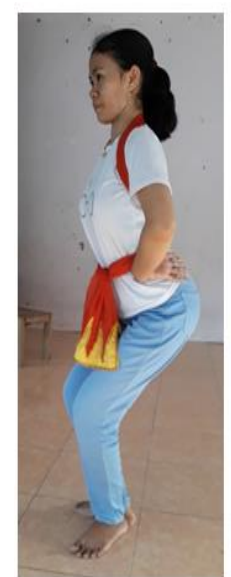

NDELENGKENG

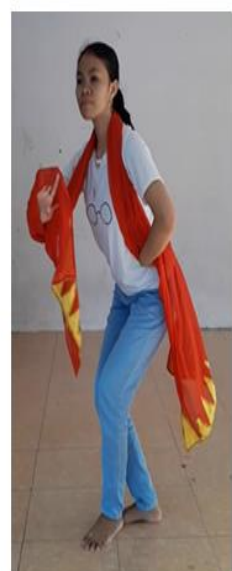

NGANGKRUK

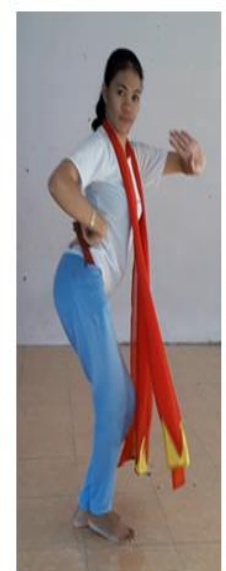

EGOL

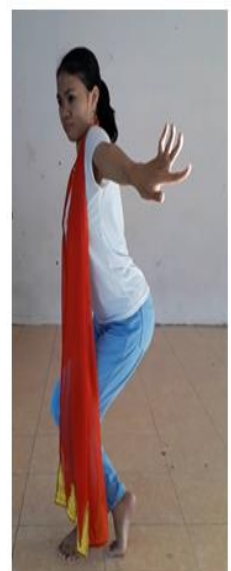

IINGKET

Figure 5. Describes the body motions (researcher documentation)

The head motions used are deleg and tolehan. Deleg can be done on the top of the head and on the chin. The head motions is shown in Figure 6.

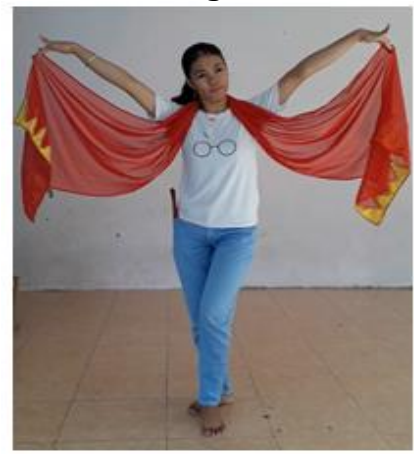

DELEG

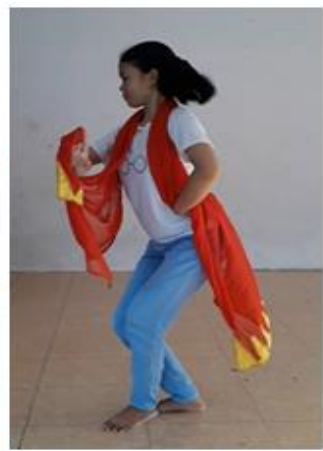

TOLEHAN

Figure 6. Describes the head motions (researcher documentation)

The hand motions contain the position of the hand and finger. The hand motions used in the GJJD dance are cangkah, ngeber, ukel, songkloh, ngayun, and sagah. Ukel is the motion of the palm of the hand which supports the wrist. The other hand motions is shown in Figure 7.

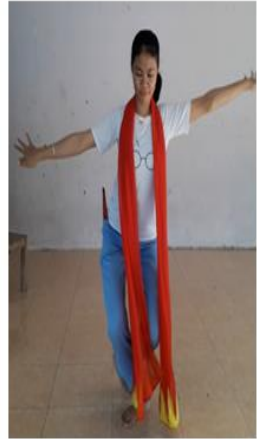

NGEBER

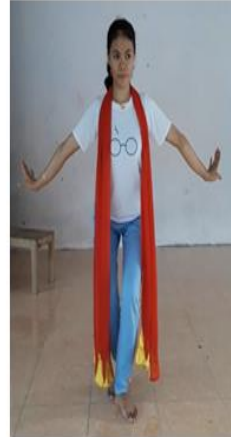

SONGKLOH

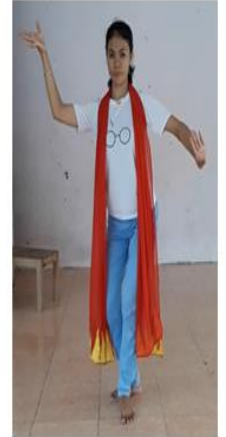

NGAYUN

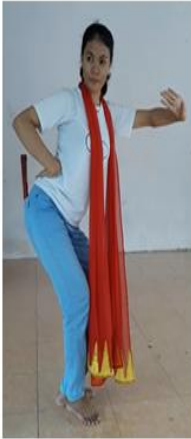

SAGAH \& CANGKAH

Figure 7. Describes hand motions (researcher documentation)

Based on the description and documentation of the GJJD dance motions performed singly, the domains of the GJJD dance motions can be determined, namely : (1) foot motion; (2) body motion; (3) head motion; (4) hand and finger motion. From the domains obtained, a taxonomic analysis can be performed based on Mathematics syllabus model of the Integrated Thematic Elementary School (Kemendikbud, 2017) in Indonesia with the results shown in the table 2 below. 
Table 2. Taxonomic Analysis Based on Domains

\begin{tabular}{|l|l|l|}
\hline DOMAIN & MATHEMATICS CONCEPT & LEVEL STUDY \\
\hline Foot motion & Counting numbers & 1 \\
\hline & Number pattern & 1 \\
\hline & Angle & 3 \\
\hline Body motion & The position of the object based on the compass point & 5 \\
\hline & Counting numbers & 1 \\
\hline & Angle & 3 \\
\hline Head motion & The position of the object based on the compass point & 5 \\
\hline & Counting numbers & 1 \\
\hline $\begin{array}{l}\text { Hand and finger } \\
\text { motion }\end{array}$ & Angle & 3 \\
\cline { 2 - 3 } & Counting numbers & 1 \\
\hline
\end{tabular}

\section{Discovering Cultural Themes}

"Culture is the result of creation, works, and intention" (Bunga, Zaenuri, \& Isnaeni, 2018). One of the creation in culture is traditional dance. Ethnomathematics can be found in tradisional dance motions and can be applied as a learning resource through the re-apllication of knowledge gained in the form of mathematical concepts for problem solving (Ma'Rifah, Widada, Aida, Yulfitri, \& Effendi, 2018; Sugianto, Abdullah, Sumarlam, \& Widodo, 2018). GJJD dance is a cultural creation that can be done singly or in groups. In this research, ethnomathematics exploration is focused on GJJD dance motions which are carried out singly.

The results showed that every motion in the GJJD dance was performed using a beat rhythm. There are several beat rhythms in footwork, body motion, head motion, and hand motion, namely : one to four beat rhythms (four beats or $n \times 4$ ) and one to eight beat rhythms (eight beats or $n \times 8$ ). In addition there are also beats on the langkah loro which has a rhythm of one to three (three beats or $n \times 3$ ). The beat rhythm in the dance motion is part of the concepts of finite counting numbers.

Footwork has four kind of steps, namely : langkah nyiji, langkah loro, langkah double step, and langkah sirig. The description of the GJJD dance motions in table 1 , shows that langkah nyiji has a pattern $1,1,1,1$ at $1 \times 4$ beats and pattern $1,1,1,1,1,1,1,1$ at $1 \times 8$ beats. This pattern can be done as a normal walking or brisk walking (in langkah nyiji kerep). Langkah loro is a langkah nyiji which is varied with the beat of the foot. Beating on the legs alternately $3 \times$ right-left-right (or vice versa), and in the fourth beat the motion returns to the first beat. So it can be said that the langkah loro has a pattern of motion 1,1,1. Langkah double step is the motion of stepping left foot twice followed by stepping right foot twice (or vice versa). This means that there is a 2,2 pattern at $1 \times 4$ beats and 2,2,2,2 patterns at $1 \times 8$ beats. While langkah sirig is footwork that uses langkah nyiji but moves sideways. So the pattern is the same as the langkah nyiji pattern.

The motion pattern of the GJDD dance is in accordance with the concept of counting. The process of counting is the determination of many objects or activities by mentioning a row of number names starting from one, and pointing to a different object or activity when the name of each number is mentioned (Khabibah, Amin, \& Lukito, 2014). The results of previous research on ethnomathematical identification in Indonesian traditional dance, still do not show the concept of counting in the dance motions.

In each domain there are angles formed between parts of the body. For example in general terms of footwork (figure 3), there is an angle formation of about $135^{\circ}$ which is an obtuse angle and an angle of about $90^{\circ}$ which is a right angle. In ngembat and sepakan (figure 4), there is also the formation of an angle of about $135^{\circ}$ which is an obtuse angle and an angle of about $90^{\circ}$ which is a right angle. Figure 5 shows that in ndelengkeng there is an angle formation on the back of $90^{\circ}<x<180^{\circ}$ which is an obtuse angle. In addition there is body motion that must be tilted (the original direction is front) either to the left or right, the body motions to the left-back-right-back to the front (or vice versa), and the motion rotates. The slope position of the body indicates the formation of an angle of $0^{0}<x<90^{\circ}$ towards the front, which is a sharp angle. Body motion turning left-back-right-back to the front shows the formation of an angle of $90^{\circ}$ towards the previous facing direction, which is a right angle. While in rotating body motion there is an angle formation of $360^{\circ}$ towards the front, which is the angle of one rotation.

The head motions used in the GJJD dance are deleg and tolehan. The descriptions of GJDD dance and figure 6 show that in the motion of deleg there is an angle formation between the position of the head shaking with the head straight up about $30^{\circ}$, which is a sharp angle. Whereas in the tolehan there is an angle formation between the position of the head turned left or right with the direction facing straight ahead about $45^{\circ}$, which is a sharp angle. The description of GJDD dance and figure 7 show that the steps 
of motion : cangkah, ngeber, ukel, songkloh, ngayun, and sagah also have angular formations. In ngeber motion, there is an angle formation of about $180^{\circ}$ between two hands which is a straight angle. Songkloh motion shows there is an angle formation about $45^{\circ}$ between hand and body, which is a sharp angle. In the ngayun motion there is an angle formation between the upper and lower hand about $90^{\circ}<x<180^{\circ}$ which is an obtuse angle. As for the sagah motion, there is an angle formation of about $30^{\circ}$ between the upper and lower hands positioned at the waist, and an angle formation about $90^{\circ}$ between the upper and lower hands which are positioned in front. The formation of these angles shows that there are acute angles and right angles in sagah motion. In sagah also contains the cangkah motion on the finger which shows that there is an angle formation of about $90^{\circ}$ between the thumb and the other four fingers which are pressed together, called the right angle.

Every GJDD dancer's body motion shows the concept of an angle. This is consistent with the results of Sandhi, et al. (2018) previous research. However, Shandi, et al. still hasn't explored all the exercises that contain the concept of this angle. An angle is a combination of two rays that are not in line and meet at the base. The concept of types of angles is explained by Susanah \& Hartono (2009) as follows : (1) angles are said to be sharp if and only if the dimensions are more than $0^{0}$ and less than $90^{\circ} ;(2)$ angles are said to be right if and only if they measure $90^{\circ}$; and (3) angles is said to be obtuse if and only if the size is more than $90^{\circ}$ but less than $180^{\circ}$

Foot and body motion are the domains that contain rotating movements. Some of this rotation is done in the form of direct rotation (forming an angle $360^{\circ}$ ), some are done in the form of partial rotation. The partial rotation performed on the footwork and body shows the position facing towards the compass point. If the initial direction of the foot and body is front (for example, in accordance with the north) then the left facing direction will correspond to the west direction, the rear facing direction will correspond to the south direction, and the right facing direction will correspond to the east direction. As showed in Figure 8. Whereas the left tilt position will correspond to the northwest direction and the right tilt position will correspond to the northeast direction.

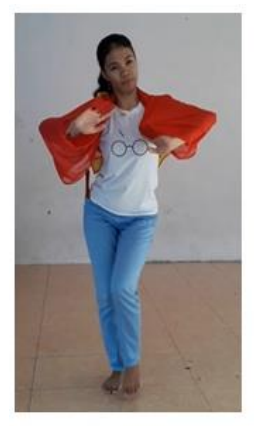

DIRECTION FORWARD

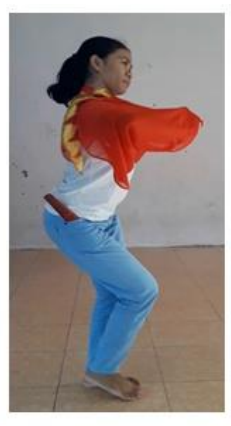

DIRECTION LEFT

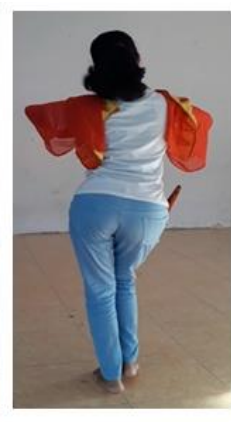

DIRECTION BACK

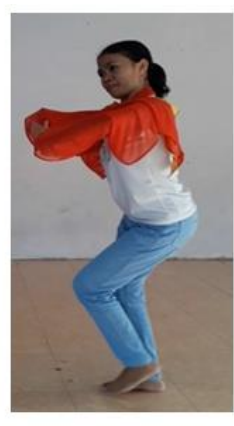

DIRECTION RIGHT

Figure 8. Describes direction towards foot and body (researcher documentation)

The directions are subject taught to students as a navigational tool for directions. Munawir (2020) explained that there are four main cardinal directions which are usually used as directions, namely : east, south, west, and north. However, previous studies on the ethnomathematics of Indonesian traditional dance still have not mentioned the concept of directions in the dance motions.

\section{DISCUSSION AND CONCLUSIONS}

GJJD dance is a traditional dance from Banyuwangi-Indonesia that has many variations of motion as described and documentation of dance motions. Traditional dance motions are generally arranged based on a deep cultural philosophy. So that the various motions contain a variety of knowledge that can be identified before being applied in learning. One of the knowledge that can be explored from traditional dance motions is mathematics. The mathematical concepts in the GJJD dance exist unnoticed by dance creators, dance trainers, and dancers, and that is part of ethnomathematics. The application of concepts known as ethnomathematics in learning will make students more active and happy to learn mathematics, especially if learning can be done by direct practice. This is in accordance with the opinion of Orey \& Rosa (2006) which states that "ethnomathematics through modeling may restore a sense of pleasure in the doing of mathematics".

The application of traditional dance motions in learning mathematics is very helpful for students who have difficulty in learning concepts that are still abstract. As Kalpana (2015) said that "dance may be an engaging and appropriate medium, to help students, especially students who are visual and kinesthetic 
learners". Students with visual and kinesthetic learning styles are expected to understand the learning concepts that are conveyed more easily through these traditional dance motion.

The application of ethnomathematics of GJJD dance to mathematics learning in elementary schools can be done in the form of thematic learning. For example : thematic learning designed with the theme "my culture" in grade 3 elementary school. This thematic learning can involve subjects of citizenship, mathematics, language (specifically involving mother tongue), sports, and arts. Thematic learning can be designed according to the competencies that are adapted from the integrated thematic syllabus model for elementary schools (Kemendikbud, 2017) in Indonesia as shown in table 3 below.

Table 3. Competence of thematic learning outcomes

\begin{tabular}{|c|c|}
\hline SUBJECTS & EXPECTED COMPETENCE \\
\hline Citizenship & $\begin{array}{l}\text { 1. Grateful for the diversity of individual characteristics in the } \\
\text { environment as a gift from God; } \\
\text { 2. Display togetherness in the diversity of individual characteristics in the } \\
\text { surrounding environment }\end{array}$ \\
\hline Mathematics & $\begin{array}{l}\text { 1. Describes the angle, type of angle (right angle, sharp, and obtuse) and } \\
\text { non-standart unit of measurement; } \\
\text { 2. Identify the type of angle (right angle, sharp, and obtuse) and non- } \\
\text { standart unit of mesurement }\end{array}$ \\
\hline Language & $\begin{array}{l}\text { 1. Read carefully the contents text about traditional dance; } \\
\text { 2. Summarize information about traditional dance in writing using } \\
\text { standard vocabulary and effective sentences }\end{array}$ \\
\hline Sports & $\begin{array}{l}\text { 1. Understand moving in a balanced, flexible, agile, and enduring manner } \\
\text { in the context of developing physical fitness through traditional dance; } \\
\text { 2. Practice moving in a balanced, flexible, agile, and enduring manner in } \\
\text { the context of developing physical fitness through traditional dance }\end{array}$ \\
\hline Arts & $\begin{array}{l}\text { 1. Know the dynamics of dance moves; } \\
\text { 2. Demonstrate the dynamics of dance motions }\end{array}$ \\
\hline
\end{tabular}

Ethnomathematics-based learning is part of the process of constructing students' understanding of certain mathematical concepts through culture that is well known in everyday life. As Brandt \& Chernoff (2014) wrote that "ethnomathematics fits well within the constructivist theory of having students build understanding and knowledge through what they have already learned and been exposed to previously". In elementary education, the initial concept construction is needed as a foothold in understanding subsequent concepts that are more complex.

The weakness of this study is that not all ethnomathematics identified from GJJD dance can be applied in thematic learning. This is because to be able to design a thematic learning, it is necessary to expand the theme to other fields. This was stated by Liu \& Wang (2010) "after finding a theme in the previous stage, this stage extends the core theme into other fields and look for the theme's focus of interest from these fields". Another weakness of this study is that it has not been able to apply thematic learning based on ethnomathematics, which had been designed in a previous discussion, in elementary school. So it still cannot be demonstrated the effectiveness of thematic learning based on ethnomathematics expected. It became an interesting thing to study and be used as further research.

Based on the classification of motion in the GJJD dance, mathematical concepts are obtained, especially in elementary school, including : numerating limited numbers, simple number patterns, types of angles and their magnitudes in general, and determining the direction on the position of motion. The identified concepts from the GJJD dance can be the basis for developing mathematics learning in particular and thematic learning by integrating these concepts with other subjects.

\section{REFERENCES}

Ain, N. (2017). Holistic Thematic Learning in the Elementary School: Is It Thematic and Holistic? International Conference on Teacher Training and Education 2017 (Advances in Social Science, Education and Humanities Research, Vol. 158) (pp. 919-928). Atlantis Press.

Boellstorff, T., Nardi, B., Pearce, C., \& Taylor, T. (2012). Ethnography and Virtual Worlds, A Handbook of Method. Princeton and Oxford: Princeton University Press.

Brandt, A., \& Chernoff, E. J. (2014). The Importance of Ethnomathematics in the Math Class. Ohio Journal of School Mathematics, Fall (71) , 31-36. 
Bunga, M. H., Zaenuri, \& Isnaeni, W. (2018). Ethnomathemtical Exploration of Palue Cultural Tribe and Its Integration. Journal of Primary Education, 7(1) , 64-73.

Charles, U., \& Justin, A. T. (2014). Towards the Theories and Practice of the Dance Art. International Journal of Humanities and Social Science, 4(4) , 251-259.

Chumdari, Anitah, S., Budiyono, \& Suryani, N. (2018). Implementation of Thematic Instructional Model in Elementary School. International Journal of Educational Research Review, 3(4) , 23-31.

Creswell, J. W. (2013). RESEARCH DESIGN, Qualitative, Quantitative, and Mixed Methods Approachs. United States of America: SAGE Publications.

D'Ambrosio, U. (2001). Ethnomathematics, Link between Traditions and Modernity. Rotterdam, The Netherlands: Sense Publisher.

D'Ambrosio, U. (2001)b. What is Ethnomathematics and how can it help children in schools? Teaching Children Mathematics, 7(6) , 308-310.

Fendrik, M., Marsigit, \& Wangid, M. N. (2020). Analysis of Riau traditional game-based ethnomathematics in developing mathematical connection skills of elementary school students. Elementary Education Online, 19(3) , 1605-1618.

Georgios, L. (2018). The Transformation of Traditional Dance from Its First to Its Second Existence: The Effectiveness of Music - Movement Education and Creative Dance in the Preservation of Our Cultural Heritage. Journal of Education and Training Studies, 6(1) , 105-113.

Greer, B., Mukhopadhyay, S., Nelson-Barber, S., \& Powell, A. B. (2009). Introduction. In B. Greer, S. Mukhopadhyay, S. Nelson-Barber, \& A. B. Powel, Culturally Responsive Mathematics Education (pp. 1-7). Routledge.

Hadi, S. (1975). CATATAN SEMENTARA TENTANG GERAK-GERAK TARI BANYUWANGI (Tidak dipublikasikan). Banyuwangi.

Hadi, S. (1980). Diskripsi Tari Jejer Jaran Dawuk. Banyuwangi: Tidak Dipublikasikan.

Hariastuti, R. M., Budiarto, M. T., \& Manuharawati. (2019). From Culture to Classroom: Study Ethnomathematics in House of Using Banyuwangi. International Journal of Trends in Mathematics Education Research, 2(2) , 76-80.

Kalpana, I. M. (2015). Bharatanatyam and Mathematics: Teaching Geometry. Journal of Fine and Studio Art, 5(2) , 6-17.

Kemendikbud. (2017). Model Silabus Sekolah Dasar/Madrasah Ibtidaiyah Tematik Terpadu. Jakarta: Kementerian Pendidikan dan Kebudayaan.

Khabibah, S., Amin, S. M., \& Lukito, A. (2014). Membantu Anak Belajar Bilangan. Surabaya: Unesa University Press.

Liu, M.-C., \& Wang, J.-Y. (2010). Investigating Knowledge Integration in Web-based Thematic Learning Using Concept Mapping Assessment. Journal of Educational Technology \& Society, 13(2) , 25-39.

Ma'Rifah, N., Widada, W., Aida, A., Yulfitri, Y., \& Effendi, J. (2018). The students' mathematics understanding through ethnomathematics based on kejei dance. SAMSES 2018 (IOP Conf. Series: Journal of Physics : Conf. Series 1318 (2019) 012079) (pp. 1-6). IOP Publishing .

Maryati, \& Pratiwi, W. (2019). ETNOMATEMATIKA: EKSPLORASI DALAM TARIAN TRADISIONAL PADA PEMBUKAAN ASIAN GAMES 2018. Fibonacci : Jurnal Pendidikan Matematika dan Matematika, 5(1) , 23-28.

Maure, O. P., \& Ningsi, G. P. (2018). EKPLORASI ETNOMATEMATIKA PADA TARIAN CACI MASYARAKAT MANGGARAI NUSA TENGGARA TIMUR. Seminar Nasional Etnomatnesia (pp. 340-347). Yogyakarta: Universitas Sarjanawiyata Tamansiswa.

Munawir, A. (Didaktika: Jurnal Kependidikan, 9(2)). Penguasaan Konsep Arah Mata Angin dengan Metode Treasure Hunt di Sekolah Dasar. 2020: 265-272.

Orey, D. C., \& Rosa, M. (2006). Ethnomathematics: Cultural Assertions and Challenges Towards Pedagogical Action. The Journal of Mathematics and Culture, 6(1) , 57-78.

Owens, K., Edmonds-Wathen, C., \& Bino, V. (2015). Bringing ethnomathematics to elementary school teachers in Papua New Guinea: A design-based research project. Revista Latinoamericana de Etnomatemática, 8(2) , 32-52.

Sandhi, N. S., Trapsilasiwi, D., Yudianto, E., Suharto, \& Sugiarti, T. (2018). ETNOMATEMATIKA POLA TARIAN JEJER JARAN DAWUK BANYUWANGI SEBAGAI INSPIRASI PENGEMBANGAN. Kadikma, 9(3) , 160-170.

Saputra, R. G., Supriyadi, \& Demartoto, A. (2019). REPRODUCTION OF JAVANESE DANCE IN SOERYO SOEMIRAT. International Journal of Education and Social Science Research , 2(2) , 97-115.

Spradley, J. P. (1979). The Ethnographic Interview. United Steates of America: Holt, Rinchart, and Winston, Inc. 
Sugianto, A., Abdullah, W., Sumarlam, \& Widodo, S. T. (2018). Reyog Ponorogo art exploration as mathematics learning resources: An ethnomathematics study. The Sixth Seminar Nasional Pendidikan Matematika Universitas Ahmad Dahlan 2018 (pp. 1-6). Yogyakarta: IOP Publishing.

Susanah, \& Hartono. (2009). Geometri. Surabaya: Unesa University Press.

Utami, N. W., Sayuti, S. A., \& Jailani. (2020). An ethnomathematics study of the days on the Javanese Calendar for learning mathematics in elementary school. Elementary Education Online, 19(3) , $1295-1305$.

Varun, A. (2014). Thematic Approach for effective communication in ECCE. International Journal of Education and Psychological Research (IJEPR), 3(3) , 49-51 